\title{
The Impact of Migration on Gender Roles: Findings of Field Research in Turkey ${ }^{1}$
}

\author{
Ayse Kadioglu*
}

\section{INTRODUCTION}

Women have become a significant factor in recent phases of post-war labour migration from the less developed to the advanced capitalist countries of North and Western Europe. Between 1957 and 1973 the majority of the recruited workers in the Federal Republic of Germany were single men who had left their families behind (Mehrlander, 1979: 147-148). However, the November 1973 ban did not lead to a sudden cessation of immigration to the Federal Republic of Germany. Rather, the composition changed because more women and children began to participate in the migration process as a result of family reunification policies. For example, the proportion of emigrant women in the flow of Turkish emigrants to the Federal Republic of Germany was only 15.6 per cent between 1961 and 1967 (Abadan-Unat et al., 1976: 12a). By the end of 1986, 32.2 per cent of all foreigners in the Federal Republic of Germany were females over 16 years of age and 22.7 per cent were children under 16 years of age (SOPEMI-OECD, 1988: 35).

Existing research on women and labour migration is concerned mainly with its impact on the emancipation of women. The most deficient aspect of this extensively studied problem is widespread use of the analytical categories "traditional" and "modern". Most analyses of post-war labour migration from industrially less developed countries of Southern Europe, North Africa and Asia to the industrially developed countries of North and Western Europe are blinded by a colonial perspective that refers to the transfer of "traditional" migrants to modern societies. Migrants are generally viewed as traditional regardless of their geographical, ethnic, cultural and religious differences. Moreover, emancipation is, in most cases, conceptualized by referring to the analytical category "modern". Hence, the indicators of modernization identified by

* Department of Political Science and Public Administration, Bilkent University, Ankara, Turkey. 
earlier studies such as Westernization, adoption of Western attitudes and customs, urbanization, access to wage work are, ipso facto, related to the emancipation of women. The major deficiency stems from total neglect of the backgrounds of these women and is caused mainly by utilization of the analytical category "traditional" in identifying the background characteristics.

Research on women and labour migration needs to go beyond limitations imposed by the existing problematique. This article suggests an alternative approach to unravel the impact of migration experiences on gender roles of women. Migration experiences of women will refer to their background characteristics in pre-migration settings and styles of exposure to migration. Analysis of the pre-migration settings of women included in this study involves an attempt to delineate background characteristics, including types of marriage and family arrangements, levels of education and work experiences outside the household in order to assess relative impact on their post-migration characteristics. Background characteristics are therefore not reduced to the general category "traditional". Second, differences among the women in terms of their exposure to migration have also been taken into account as part of their migration experiences. This has led to the distinction between initiators or pioneer women who emigrated without their husbands and followers who joined their husbands abroad. The followers are further classified according to the presence or lack of wage work while abroad. As migration experiences are not reserved only for migrant women, the leftbehind women are also included in the study.

The main focus of the research is changing gender roles of women rather than their emancipation. Gender roles, as widely accepted in the literature on women's studies, refer to socially-constructed sex roles, i.e. they identify roles that women and men are expected to fulfil. Instead of studying whether women who were exposed to migration are emancipated or not, the present study attempts to unravel whether migration has led to a change of gender roles. The study therefore addresses presence or lack of patriarchal control in the identification of gender roles. Structural and psychological variables have also been taken into account. The former includes women's access to social security benefits and bank accounts, their ability to visit family and friends without being chaperoned as well as their style of voting. The psychological variables refer to women's self-perceptions and views on issues such as women and work, marriage, family and the discipline of children.

The present study attempts to shift the problematique towards gender roles rather than grappling with emancipation. Contrary to the category of emancipation, that ipso facto is derived from various indicators of 
modernization, gender roles are a more analytical category. Instead of arguing, for instance, that exposure to Western culture and modernization necessarily lead to the emancipation of migrant women, the present research studies certain variables related to gender roles of women who have experienced migration. Women included in the study are not labelled as emancipated or traditional but rather evaluated according to those roles. The particular conceptualization of the category gender roles shifts the focus of the study towards types of intra-family division of labour. The study also takes into account different migration experiences rather than referring to the migration act as an independent variable. Migration experiences are conceptualized in such a way as to incorporate certain background characteristics of the women included in this study.

\section{WOMEN AND LABOUR MIGRATION: A REVIEW OF THE LITERATURE}

Literature concerning the impact of migration on the socio-economic status of women can be categorized into three groups according to the key research questions that were raised. One group refers to migrant women as social problems characterized by their stereotypical, traditional backgrounds. They are defined within the framework of the family unit as dependent wives and mothers who are unproductive, illiterate, isolated and bearers of children. As Andezian (1986: 257) concludes, "They (the migrant women) do not speak the language of the host society, do not know how to read, nor write, and because they do not work, they have no resources of their own."

These traits are attributed to most migrant women regardless of their specific ethnic and cultural origins. They are viewed as a problematic group who are structurally inferior and therefore need adaptation and/or integration into the host society. It is assumed that emigration and subsequent integration into the host society will accelerate the move from tradition to modernity at an individual attitudinal level. When the backgrounds of all migrant women are simply defined as traditional, this concept loses all analytical importance. Migrant women are viewed as accessories of men whose traditional ways need to be changed.

The second group of writings refer to migrant women as social actors. This view assigns primary importance to the work performed by women in the labour market of host societies, including whether their participation in the labour market leads to emancipation. In most cases, the characteristics associated with an ideal-typical modern society are believed to be the cause of emancipation. These characteristics include 
urbanization, adoption of nuclear family patterns, entry into the wage labour market, and increasing media exposure. In a seminal article on emancipation being closely related to the process of modernization, Abadan-Unat (1977: 35) develops a set of criteria to measure degree of emancipation caused by emigration along these lines.

- decline of extended family relations,

- adoption of nuclear family role patterns,

- fragmentation of family structure,

- entrance into a wage earning production process,

- increasing media exposure,

- decline of religious practices,

- increasing belief in egalitarian opportunities of girls and boys in terms of education, and

- adoption of consumption oriented behaviour and norms.

Many authors emphasize one or more of these criteria in asserting that emigration of women ipso facto leads to an improvement in lifestyles and hence emancipation. As articulated by Foner (1979: 22), “...regardless of other drawbacks that residence in England has for Jamaican women, the chance to earn a regular wage has led to a dramatic improvement in their lives."

Agricultural transformation, differentiation, depeasantization and the consequent entry into the wage market are all factors that are considered to pave the way towards modernization and emancipation. As Tienda and Booth (1991: 56) argue:

Beliefs that migration improves women's position are predicated on suppositions that geographical movement involves shifts from more to less oppressive environments (i.e., to overcome taboos on outof-wedlock births or to escape from highly uneven and rigid sex hierarchies); that participation in remunerated activities is preferable to participation in unremunerated activities; and that market activity ensures greater authority and autonomy in the redistribution of family resources. Alternatively, arguments that migration erodes women's position are based on evidence of fewer opportunities for female employment; lesser control over earnings and reduced participation in family decision-making; a loss of independence and greater control by men; and the disruption of family relations through separation and divorce (italics as in the original).

Kosack (1976), assumes that active involvement in the production process, having the same power as all productive workers and getting 
involved in their struggles, are preconditions for migrant women's emancipation. Authors who can be classified under this second group have provided a great deal of information on migrant women as social actors rather than accessories of their husbands, fathers or brothers. Yet they also adopt a sociological perspective that evaluates movement from traditional to modern societies as a development that relieves women from oppression that they suffer in their home societies. Western ways are therefore viewed as emancipatory and what follows is a perspective that clings to colonial ideology in stating that wage work is a gift offered to the migrant women of the Third World by the West in their struggle against oppressive traditions in their home societies.

The third group of writings attempts to go beyond a modernization/ emancipation outlook. For instance Morokvasic (1983: 23) criticizes studies that do not take into account the specific socio-cultural backgrounds of migrant women:

Indeed, women migrants are treated only as immigrants, lives analysed from the moment they enter the new country. The stereotype of "traditional women" implies that migrant women are tabulae rasae as regards certain norms and behaviour (such as birth control and access to waged work) attributed to the immigrant society, and any difference from the stereotype is interpreted as a change towards the adoption of new models (supposed to be promoting, liberating, emancipatory).

The tendency for some academics to refer to the nature of interpersonal relationships in migrants' home societies as backward, oppressive and hence traditional, rules out any interest in studying these societies. Migrant women that reside and/or work in today's North and West European societies come from a variety of backgrounds with ethnic and cultural differences that are both inter-national and intra-national. Morokvasic (1983: 23) maintains that whatever change takes place due to migration should be seen as a "continuation of a trend initiated before the emigration process and as a consequence of the interaction between the migratory and background influences". Her approach is vital in bringing to the forefront the significance of the backgrounds of migrant women.

The authors in the third group do not take for granted that urbanization, wage labour, or adoption of nuclear family patterns necessarily pave the way towards emancipation. They rather focus on the specific characteristics of migrant women's cultural backgrounds and study the change that occurs upon arrival, residence and work in the host society (Engelbrektsson, 1978). They do not have any preconceptions regarding the direction of this change. 
This approach enabled Brouwer and Priester (1983), who studied Turkish women in their homeland and in the migration setting (Netherlands), to conclude that migration and wage earning do not weaken male control over women. They suggest that participation in the production process does not necessarily result in emancipation and that sexual division of labour is more than an allocation of activities in the production process. It implies "a power relationship between the sexes - in which women are controlled by men - mediated by ideology"(1983: 114). These authors studied the nature of this control mechanism in a rural village located in central Turkey. They conducted their research around the axes of gender identity, marriage and labour and focused on the impact of migration on such control mechanisms both for women left behind in the village and the migrant women who moved to the Netherlands. Accordingly, they observed these women within the context of intra-family relationships in the Netherlands and found evidence of increased control of husbands over wives in the form of reduced freedom of movement. When intrafamily control mechanisms over migrant women's earnings are also taken into account, one develops an entirely new perspective on wage labour and emancipation: "...access to a wage does not necessarily imply control over the spending of that wage. The majority of Arpa (name of the village) women give their money to their husbands without apparent conflict..." (1983: 127).

This observation seriously challenges conventional wisdom concerning the relationship between participation in production process and emancipation. Moreover, these authors depict new problem areas by pointing to the type of work performed by migrant women, generally unskilled manual work in laundries, cleaning, clothing, textiles and food industries. Turkish migrant women's overrepresentation in underpaid, menial jobs requiring no qualifications was also highlighted in a later study by Abadan-Unat (1982: 214). Davis and Heyl (1986: 193) also reported that jobs held by Turkish women in Germany included domestic work, textile manufacture, television parts or assembly, tailoring, chemical processing, auto manufacture, clerical work and teaching.

Despite frequent utilization of the concept emancipation, Abadan-Unat is one of the few authors who has grappled with its meaning. Concerning the spending, saving and investment tendencies of Turkish migrant women, she noted that "freedom for consumption does not necessarily mean the liberty of choosing a different way of living....Thus we may ask whether economic affluence and the cult of foreign consumer goods can serve as a criterion for emancipation" (1982: 219). However, she also maintains that,

It is possible to conclude that the entrance of foreign women workers into complex industrial enterprises of developed countries should not be 
looked upon as an unsuccessful venture. In spite of migrant women's difficulties in terms of adjustment, industrial jobs and even menial ones expose migrant women to factory work, discipline, awareness of time, punctuality, trade union activity, and access to social security, all of which were unknown to most of them prior to their departure from their home country. In addition, environmental conditions in satisfactory housing, life in big cities, and increased exposure to mass media prepare the ground for emancipatory actions (Abadan-Unat, 1982: 216).

The findings of the present research lend some credence to these observations.

\section{THE IMPACT OF MIGRATION EXPERIENCES ON GENDER ROLES}

\section{Sample selection and research sites}

In the field research, four types of women involved in or affected by external migration were identified:

1. Initiators or the pioneer women (PW), the first in their family to emigrate. They may have emigrated on their own initiative when they were single or left their husbands behind, mainly because more jobs were available for women.

2. Followers with wage work experience abroad (FW), who joined their husbands or emigrated together with them and had access to wage work in host societies.

3. Followers without wage work experience abroad (FW/out) whose activities were mainly within the household while abroad and did not acquire work experience outside the household.

4. Women who were left behind (LB) upon the emigration of their husbands.

In addition to the women who have experienced either their own or their husband's emigration, a non-migrant control group, selected proportionately from similar research sites, served as a basis of comparison.

The surveys were conducted in three different sites - an industrial metropolis, a provincial industrializing town, and various rural villages within the same region - classified according to levels of industrial development, economic diversification and urbanization. Such a clas- 
sification ensured the economic and psychological variety of study subjects. The specific study locations were:

- an industrial metropolis: Ankara. While not the key returning city, it represents a variety of settlement patterns and a variety of employment types for male and female returnees.

- a small, provincial, industrializing town: Kisehir. Located about 200 kilometers to the south and east of Ankara, it represents a town inhabited by returnees of different ethnic and religious origins.

- rural villages in the province of Kirsehir, located 15 to 20 kilometres from Kirsehir: Kortulu, Karakurt, Karacaören, Toklümen, Siddikli, Cepni, Barakli, and Akbiyikli. These villages experienced mass migrations and contain many women left behind. ${ }^{2}$

The researchers followed two methods in selecting the sample. The first involved an examination of files kept by the Social Insurance Institute in Turkey which contain the names and addresses of returnees. Most of the migrants in the sample returned during 1984 mainly in response to a premium paid by the Government of Germany to encourage return. Returnees included in the sample had been back in Turkey for at least two years and had therefore experienced an adequate period of adjustment. The names and addresses of about one thousand returnees were acquired from the Social Insurance Institute. ${ }^{3}$

Second, the chain inquiry method was used in selecting the sample. Researchers went to neighbourhoods populated by returnees and with a little help from the local grocery store, bakery or other local shopkeepers, the addresses of returnees in the area were obtained. Some of the storekeepers were themselves returnees. Indeed, in some neighbourhoods, 7 out of 20 flats in complexes were occupied by returnees.

During the selection process researchers experienced difficulties in finding pioneer women (PW) among returnees settled in Ankara. This led to further research in the Istanbul region. Most of the pioneer women who had initiated emigration were originally from the Istanbul area and had returned there in large numbers. Istanbul was therefore used as a supplementary research site for pioneer women.

In the present research, 215 women were interviewed: 116 who emigrated either as pioneers or followers, 45 who were left behind upon the emigration of their husbands and 54 "controls". The sample group breakdown is as follows: 
Pioneer women (PW)

Followers with wage work experience (FW) 44

Followers without wage work experience (FW/out) $\quad 39$

Left-behind women (LB) 45

Controls $\quad 54$

Total 215

\section{Rationale for the classification of data}

Typologies of migrant women based on instigation to leave the home country were suggested in early literature (Abadan-Unat, 1982: 212). In the present research, classification of data according to styles of exposure to migration (pioneer women, followers with work experience abroad, followers without work experience abroad, women who were left behind upon the emigration of their husbands) was meaningful at two levels.

First, in the course of the preliminary survey, various cases of pioneer women were observed who had led their families in the migration process and displayed more independent, initiative-laden behaviour patterns compared with their dependent, follower counterparts. These observations seemed to verify the findings of a field survey by Davis and Heyl (1986: 192) on pioneer Turkish women which identified a female-first migration stream, especially when the women were married at the time of the move. This had the impact of reversing former domestic roles.

Some pioneer women were married prior to emigration and left their families behind until they could make arrangements for family reunification. Forced to live alone temporarily in the host society, they had the freedom to critically evaluate the terms of their existing family arrangements and intra-family divisions of labour. Moreover, some pioneer women emigrated while they were single and were later married in the migraton setting. Their migration experience seemed to have an impact on their marital relations from the outset. Those women who were left behind in the home society unchaperoned by their in-laws also had access to a similar type of freedom of space. They could also critically evaluate the terms of their family arrangements. The cases in which migration gave women the opportunity to critically evaluate their family arrangements from a distance displayed some similarities in terms of gender roles in the preliminary survey. Classification and comparison of data in terms of styles of exposure to migration therefore seemed meaningful. In addition to pioneers and followers, women left behind were also included in this classification and comparison, since by being left behind in an unchaperoned environment they had access to the aforementioned freedom of space. 
Second, the sample was classified according to styles of exposure to migration because such a classification indirectly contained information on the backgrounds of respondents. In the course of the preliminary field survey, four background variables appeared to be significant in influencing the migration experiences of women: marriage types (arranged or romantic); family types (extended or nuclear); levels of education; and the presence or lack of wage work experience outside the household prior to emigration. Marriages arranged by the elder members of families are quite common in Turkey and the intra-family division of labour that such marriages produce is more patriarchal when compared with the friendly and egalitarian husband-wife relations generated by romantic marriages in which spouses express a clear wish to live together. Moreover, women who live in extended families with their husbands' kin seemed more constrained in their behaviour compared with women in nuclear families. Researchers also noted in the preliminary field survey that the education of migrant women and women left behind seemed to have an impact on their gender roles. The preliminary survey also indicated that work experience outside the household prior to emigration influenced the migration experiences of the women. These cases generated hypotheses relating to the aforementioned four background variables and the four styles of exposure to migration. The documentation and analysis of data presented below will begin by testing these hypotheses.

\section{Documentation and analysis of the data}

\section{Relating background variables to styles of exposure to migration}

Hypothesis 1: A substantial number of the romantically married women had become pioneers in emigration whereas most of the women in arranged marriages had become dependent followers.

Table 1 (page 555) indicates that the majority of the pioneer women had romantic marriages whereas the majority of followers had been married through family arrangements prior to emigration. A substantial number of followers without work experience had arranged marriages compared with followers with work experience. This particular finding may mean that husbands in romantic marriages based on friendly partnerships allow their wives to work outside the household.

Hypothesis 2: A substantial number of women in nuclear families have become pioneer migrants whereas most of the women who lived in extended families with their husbands' kin have either become dependent followers or were left behind.

Table 2 (page 555) indicates that women who lived in nuclear family arrangements had more freedom of movement compared with women in 
extended families in pre-migration settings. Whereas 88 per cent of pioneer women were originally from nuclear families, 61 per cent of followers with work experience abroad, i.e., with more freedom of movement in the host society setting, also had nuclear family patterns prior to emigration. On the other hand, a majority of followers without work experience abroad and women who were left behind were originally from extended families.

Hypothesis 3: Women with higher levels of education prior to emigration have a higher tendency to become pioneer migrants when compared with women with lower levels of education.

Table 3 (page 555) indicates that better educated women display a greater tendency to initiate emigration whereas the majority of uneducated women in the sample either accompanied their husbands to the migration setting where they remained unemployed dependents or were left behind.

Hypothesis 4: Women with wage work experiences outside the household prior to emigration have a tendency either to initiate emigration or to work for wages in the migration setting.

Table 4 (page 556) indicates that women with wage work experience outside the household prior to emigration had a greater tendency to become pioneer migrants whereas all the left behind women in the sample and 95 per cent of the followers without work experience abroad were unemployed in pre-migration settings.

An evaluation of Tables 1-4 indicates that pioneer women were more likely to be involved in romantic marriages and had nuclear families prior to emigration. Moreover, they had higher levels of education and a greater likelihood of having had wage work experience. The background characteristics of the women in the sample change towards arranged marriages, extended families, lower levels of education and the absence of work experience prior to emigration as one moves along a scale from followers with work experience abroad to followers without work experience abroad and finally to women who were left behind upon the emigration of their husbands. Hence, the classification and comparison of the data on gender roles according to styles of exposure to migration not only signifies differences in patterns of emigration but also in certain background characteristics of the women included in this survey. The categories of pioneer women, followers with work experience abroad, followers without work experience abroad, and women who were left behind upon the emigration of their husbands, signify styles of exposure to migration as well as certain background characteristics. Therefore, 
these categories refer to the totality of the migration experiences which reflect styles of exposure to migration as well as the four background variables.

The present research focuses mainly on the impact of migration experiences of women on their gender roles. Migration experiences, as explained above, include the categories of pre-migration settings and styles of exposure to migration whereas gender roles are identified by a set of structural determinants as well as psychological determinants. The correlations between the two aspects of migration experiences - premigration settings and styles of exposure to migration - have already been established in Tables 1-4. These findings pave the way to categorization of migration experiences according to styles of exposure to migration. Nevertheless, it must be emphasized that migration experiences refer to a category larger than the category of styles of exposure to migration since it also includes certain background variables associated with pre-migration settings. According to the delineation of the categories utilized in this research, the category pioneer women, for instance, no longer represents only a style of exposure to migration but also a migration experience since it makes references to marrriage and family types, levels of education, and the existence or lack of work experience outside the household prior to emigration. In other words, according to Tables 1-4, pioneer women not only initiated emigration on their own but also came from romantic marriages, nuclear families, had higher levels of education and work experience outside the household prior to emigration. Before comparing different migration experiences by gender roles, a general comparison of the 116 migrant women (excluding the women who were left behind) and the control group (54 women who did not experience migration either on their own or through their husbands' emigration) will be presented in order to comprehend the impact of the migration act on gender roles.

Comparing Migrant and Non-migrant/Control Groups:

Does the Migration Act Itself Make a Difference?

Data on the 116 migrant women, regardless of whether they were pioneers or followers, indicate that 75 ( 65 per cent) emigrated between 1968 and 1974 whereas 22 (19 per cent) emigrated after 1980. Fifty-one per cent of the 116 migrant women returned to their home societies between 1983 and 1985 . The reason for this high return rate is that most of the original migrants had reached retirement age and chose to benefit from the 1983 premium payments allotted returnees in the Federal Republic of Germany. Almost 65 per cent of migrant women in the sample stayed abroad for more than ten years; 56 per cent were less than 24 years old; 85 per cent of them were married at the time of emigration. 
Concerning the impact of migration, 25 per cent of the migrant women said that it had given them a chance to work and contribute to the family's income, 19 per cent that it made them more tired and worn out, 18 per cent that it had provided an opportunity to get out of the house and to enhance themselves; only 6 per cent said that it had enhanced dependence on their husband and 4 per cent that it had increased their husbands' control over them. When asked to compare themselves with non-migrant women, 61 per cent said that they now viewed themselves as more mature, knowledgeable, aware and less shy than the nonmigrant women in their community, whereas 13 per cent pointed to financial improvement in their status.

Table 5 (page 556) indicates that 88 per cent of the 116 migrant women became housewives upon their return home even though some had worked outside the household while abroad. While 8 per cent indicated that they helped with the family work outside the household, only 3 per cent worked in other jobs. On grounds that 92 per cent of the non-migrant control group were housewives and 6 per cent helped with the family work outside the household, it is clear that the migration experience had no bearing on work experience outside the household upon return.

Comparison between migrants and the non-migrant controls in relation to structural determinants of gender roles indicate that in the case of financial old-age securities there is no significant difference: 63 per cent of the migrant women had no social security benefits, compared with 77 per cent for the non-migrant control group (Table 6, page 557). It may therefore be argued that prior migration experience is related neither to women's work experience outside the household nor to social security status upon return. On the other hand, only 27 per cent of the migrant group said that they never had a bank account of their own compared with 82 per cent for non-migrants.

Another structural indicator of gender roles is ability to visit friends and family outside the household. Table 6 indicates that when compared with their non-migrant counterparts, migrant women are less controlled while visiting friends and family in the post-migration setting: 69 per cent of the migrant women said that they could go wherever they want without their husbands' and/or in-laws' permission, compared with 22 per cent for the non-migrants.

Table 6 also indicates that 63 per cent of migrant women would normally vote for the political party of their own choice even if this was not their husbands' choice. The corresponding figure for the non-migrants is 39 per cent. Forty eight per cent of the non-migrants said that their husbands would tell them who to vote for, compared with 22 per cent for the migrant women. 
Most of the indicators presented in Table 6 - access to individual bank accounts, control over visits to family and friends and voting - point to a change in the structural determinants of gender roles that appear to have been attributed to the migration experience. The two groups display similarities only in relation to access to social security benefits.

In terms of the psychological determinants of gender roles, response to the proposition that "Women should give up their work/career if it conflicts with the husbands' and/or familys' well-being" indicated that 50 per cent of the migrant women either strongly disagreed or disagreed compared with only 12 per cent of non-migrant women (Table 7, page 557). Indeed, 62 per cent of the non-migrants strongly agreed with the statement. When asked if they agreed with the statement: "Stricter discipline should be employed in raising girls", 64 per cent of the migrant women disagreed (combination of strongly disagree and disagree answers) compared with 45 per cent for the non-migrants.

Tables 6 and 7 together indicated that both the structural and psychological determinants of gender roles point to significant changes regarding real life experiences and perceptions of women that are clearly attributed to migration.

\section{Impact of different migration experiences on gender roles}

\section{a. Migrant women and housework}

When asked about their involvement in activities such as housework and child-care while abroad, 42 per cent of the pioneer women said that they had been very much involved in such work; the corresponding percentages for the followers with work experience abroad, and followers without work experience abroad, were 50 and 77 respectively. This suggests that no matter what other activities they may be involved in, all migrant women still view themselves as responsible for housework and child-care. As a result, those who work outside the household suffer the double burden of employment and housework.

\section{b. Structural determinants of gender roles}

An evaluation of the findings in Table 8 (page 558) relating to access to social security benefits suggests that the followers without work experience abroad are more disadvantaged compared with pioneer migrants and followers who had access to wage work experience abroad. The differences between the former two and the latter two groups taken together are more striking than the differences among each group. Such a finding can be taken as another indicator of the significance of wage 
work experience while abroad. In other words, migration does not seem to be a sufficient condition in affecting the existence or lack of such benefits unless it is accompanied by work experience. Interestingly, the status of the women who were left behind seems slightly better than that of the followers without work experience abroad in terms of access to such benefits. The findings in Table 8 also suggest that more pioneer women have access to individual bank accounts when compared to other groups. More left behind women in the sample ( 52 per cent) have individual bank accounts compared with the followers without work experience abroad ( 23 per cent). Women who were left behind upon the emigration of their husbands appear to be more advantaged regarding this issue compared with the followers without work experience abroad. This is probably an advantage that they acquired during their husbands' absence. The findings in Table 8 point to the fact that the pioneer women and the followers with work experience abroad can display more independent behaviour and that the differences between the pioneer women and followers with work experience abroad on the one hand, and followers without work experience abroad and the women who were left behind on the other, display more striking differences when compared to the differences among each group. These findings further support the observation that migration is not a sufficient condition in affecting gender roles unless it is accompanied by wage work experience abroad.

\section{c. Psychological determinants of gender roles}

A comparison of the four types of migration experiences in terms of the psychological determinants of gender roles indicates that the pioneer women and the followers with work experience abroad have adopted a more questioning attitude towards the patriarchal nature of gender roles. Table 9 (page 558) underlines striking differences between the pioneer women and the followers with work experience abroad on the one hand, and the followers without work experience and the women who were left behind on the other, thus providing further support for the observation that migration by itself is not a sufficient condition in affecting women's self-perceptions and views on issues such as the discipline of their daughters, and intra-family division of labour.

\section{Women left behind}

There was some change regarding the structural dimensions of gender roles of women who were left behind upon the emigration of their husbands. Fifty-three per cent said that they became the head of their households upon their husbands' emigration, and more than half indicated that there had been a significant change regarding their status within the family. About 62 per cent maintained that they had become 
responsible for going to town for shopping, bargaining in the marketplace, doing business at the bank, and obtaining medical care for themselves and their children, and 58 per cent indicated that they had become more active in arranging social activities concerning the family such as weddings, circumcision and other ceremonies. About 73 per cent of the women left behind said that they had become more involved in the education and discipline of their children. About 64 per cent of these women indicated that their husbands had sent their savings directly to them and 75 per cent claimed that they were responsible for daily household expenditure. However, 75 per cent said that their husbands made decisions concerning the buying of house, land, tractor, car, etc. Almost 66 per cent of the left behind women reported an increase in their husbands' trust as a result of their survival during his emigration. When asked about positive changes resulting from their husbands' emigration, 50 per cent gave primary importance to financial betterment, 11 per cent nominated increased respect that they had received from their children, and only 7 per cent indicated that they had become more independent. Interestingly, 18 per cent said that they realized the importance of their husbands in their lives. When related to the fact that 58 per cent of the left behind women complained about being forced to live alone, it is clear that the major misgiving they had about their status was their husbands' absence. This finding seems to contradict Brink (1991) who concluded from her survey of a village in Egypt in 1983-1984 that: "Rural Egyptian marriages are not based on love...separation from their spouses was not as difficult as it would be for a couple whose marriage is based on romantic love...Traditional women do not expect nor want to spend time with their husbands" (1991: 208).

\section{CONCLUSIONS}

Women who have been exposed to the migration experience either by emigrating themselves or by being left behind upon the emigration of their husbands have lost some of the fatalism they had in pre-migration settings and acquired more individualistic, independent, risk-taking, initiative-laden behaviour patterns when compared with the nonmigrant control group. This result has been reached not only by a comparison of the behaviour patterns of the two groups but also in the migrant women's self-perceptions when asked to compare themselves to non-migrants in the return context. Yet, the acquisition of such behaviour patterns has also increased the frustrations of migrant women unable to find appropriate outlets (jobs or social activities) outside the household in the return context. Since they perceive themselves as a separate group, they have difficulties relating to non-migrant neighbours. Ironically, even though on the one hand they may despise 
non-migrant neighbours for being fatalistic and old-fashioned, they also complain about not being able to have community relations with them. They seem clearly frustrated and alienated in the return context, observations which support Davis and Heyl (1986: 194) who maintain that returning migrants are usually not accepted as legitimate members of the middle class unless they have become outstandingly successful.

Second, neither emigration itself nor different migration experiences (PW, FW, FW/out, and LB) have a bearing on women's work experiences upon their (or their husbands') return home. Even though they may have had work experience abroad for prolonged periods of time, most migrant women cease working outside the household upon their return, due largely to lack of appropriate jobs. Moreover, in most cases, the type of work experience acquired abroad neither provides them with skills nor directs them towards further employment in the return context. Most migrant women view their work experience abroad as a temporary mechanism to supplement family income and savings. Previous research suggests that migrant women leave paid employment as soon as their family economic situation improves (Simon and Brettell, 1986: 12). It has also been suggested that migration results in "restructured inequities" since gender asymmetries are left intact (Tienda and Booth, 1991: 67). Accordingly, when women migrants perceive themselves as temporary sojourners who obtained paid employment to supplement the financial resources of their families, migration may simply transfer patriarchal authority to the host society context. Tienda and Booth argue "That migrant women's entry into paid employment usually arises because of dire necessity and leaves patriarchal authority essentially unaltered puts a brake on the extent to which migration can modify gender relations" (1991: 67).

Because work outside the household does not alter their status within the family regarding responsibility in housework, cooking, cleaning, and caring for the children, most migrant women maintain that while abroad they suffered the double burden of work in both the public domain and the household. Hence, in the return context, they are only financially better off than their non-migrant counterparts. In terms of intra-family division of labour, the two groups do not display significant differences. Returning migrant women continue to play some roles within the public domain. Yet, acquisition of such roles does not alter division of labour within the household. The pioneer women and followers with work experience in our survey complain about early ageing, deformation and illnesses caused by increased workloads in the migration setting. They complain about becoming less feminine due to time-constraints, i.e. not having enough time to take care of themselves. This has probably paved the way to their noticeable hostility towards women who emphasize their sexuality by putting on make-up and wearing "promiscuous" clothes. 
It is obvious that the social position of migrant women is determined at the controversial boundary between tradition and modernity where they have been burdened with the role of balancing actors. Such a difficult role is obviously manifested in their psyches and perceptions. They display hostility both towards women who, in their opinion, are too traditional, i.e. wearing traditional clothes, covering their heads, displaying fatalistic and religious behaviour patterns, and women who have become too westernized. The role of migrant women in the host society as gatekeepers of their native culture has been depicted by Andezian (1986) who elucidated Algerian women's active involvement in the organization of an Islamic community in France. Accordingly, these women alleviate stress caused by the social disorder generated by immigration among the migrants, and hence contribute to the reduction of social entropy.

Third, when compared with the non-migrant control group in terms of the structural determinants of gender roles, such as access to social security benefits and a bank account of their own, ability to visit family and friends without supervision, and freedom to vote for a political party of their own choice in national elections, migrant women clearly display more independent behaviour patterns. A similar trend is observed regarding the psychological determinants of gender roles, such as their self-perceptions and views on women and work, marriage, family and discipline of children. Hence, it is possible to observe a significant difference between the gender roles of the women who have been exposed to migration either by emigrating or by being left behind and the non-migrant control group. Nonetheless, it is important to note that such changes do not alter the intra-family division of labour in a fundamental way.

Fourth, when women in the survey are compared according to their migration experiences (PW, FW, FW/out and LB) in terms of structural and psychological determinants of gender roles, the pioneer women and the followers with work experience abroad do not appear to be significantly different. Moreover, gender roles of the followers without work experience abroad and the left behind women do not appear to be significantly different either. Rather it is the differences between the former two (PW and FW) and the latter two (FW/out and LB) that are more striking. In other words, pioneer women display similar behaviour patterns to the followers with work experience, and the followers without work experience display similar behaviour patterns to the women who were left behind. These findings suggest that migration by itself is not a sufficient variable in affecting gender roles unless accompanied by work experience abroad. In spite of the fact that the type of work experience in host societies did not usually prepare these women 
for future employment, it undoubtedly increased their feeling of independence. Still, one should not exaggerate the change in gender roles of these women caused by emigration and employment as most of them complained about the deforming effects of the double burden caused by work at home and outside the house. The negative impact of this double burden was also depicted by Tienda and Booth (1991: 53) who maintain that "market activity simply compounds women's overall workload." Other negative results of emigration were also quite apparent in cases when migrant women, faced with the impossibility of combining child care and paid employment, sacrificed their role as mothers and left children behind with their parents or in-laws. Separation from their children for prolonged periods of time made these women very unhappy.

Moreover, it is possible to observe a slightly more significant alteration in gender roles of the left behind women compared with followers without work experience as the former's responsibilities within the household were inevitably enhanced due to their husbands' absence and they proved themselves more capable of taking certain family decisions on their own. Therefore, followers without work experience abroad are the most disadvantaged group in terms of release from patriarchal control as their activities have been constantly scrutinized by their husbands in the migration setting. Still, it would be wrong to draw a conclusion indicating the release of the women who were left behind from patriarchal control because most of them resumed their prior roles upon their husbands' return. It was possible to observe many psychological and psychosomatic illnesses on the part of left behind women, most of whom complained about the difficulties generated by prolonged loneliness accompanied by enhanced family responsibilities. Such complaints were more common among the left behind women who did not stay in their home-village setting and emigrated to big cities as extended families. These women were forced to live under the supervision of their in-laws in an unfamiliar environment. The left behind women who were more educated and lived in an urban setting as the heads of their own nuclear families without being supervised by their in-laws were more successful in establishing for themselves an independent space.

An ever-increasing literature on women and migration revolves around the issue of whether migration leads to a loss or gain in the status of women. This can be assessed only by taking into account changes regarding division of labour within the family. The paradoxical impact of migration on women's status has been astutely summarized by Tienda and Booth who argue that "Migration simultaneously can bring gains and losses for women if a greater degree of autonomy in public and private domains is accompanied by a heavier workload" (1991: 55). 
Previous research suggests that the impact of migration on women's status varies with both the immigrant context and cultural background (Simon and Brettell, 1986: 14). It has also been suggested that the consequences of migration depend on marital status (Tienda and Booth, 1991: 69). The apparent similarity between the findings of our research regarding pioneer women and followers with work experience on the one hand, and followers without work experience and the ones who were left behind on the other, points to the significance of work experience in the receiving societies in giving shape to gender roles. It is obvious that it is not migration per se that alters gender roles. Migration at best is a catalyst that triggers a change in gender roles that are also shaped by an interplay of other variables such as the immigrant context and migrant women's background experiences.

In sum, pioneer women with romantic marriages and nuclear families as well as higher levels of education and prior work experience outside the household display more significant levels of release from intra-family patriarchal control in terms of structural and psychological determinants of gender roles. A similar trend can also be observed in the case of followers who had access to wage work experience while abroad. Women left behind who continued to live in an environment in which they were closely supervised by their extended family did not experience a drastic release from patriarchal control in terms of gender roles due to their husbands' emigration. Women who were left behind in nuclear families, unchaperoned by their extended kin were, on the contrary, forced to take upon themselves certain new roles within the public realm in addition to being single parents and caring for the household. A substantial number of these women acquired individual bank accounts as well as an upper hand in matters regarding the raising and discipline of their children. The followers without wage work experience abroad, most of whom came from arranged marriages and extended families with low levels of education, and no work experience prior to emigration, seemed to be the most disadvantaged group in terms of both access to certain areas within the public realm as well as intra-family division of labour and patriarchal control.

When the four types of migration experiences are compared with each other in terms of gender roles, differences between the pioneer women and the followers with wage work experience abroad seem less striking when compared to the followers without work experience abroad and the women who were left behind. This finding alone is an indicator of the importance of exposure to work experience abroad. Hence, it is possible to conclude that the impact of migration experiences on gender roles is determined by an interplay of background factors as well as exposure to wage work experience while abroad. 
The survey on the impact of migration experiences on gender roles of Turkish women indicates that the former is a significant variable in determining the latter. The impact of migration on gender roles is enhanced when accompanied by work experience abroad. Most of the migrant women in our survey themselves point to a change in their behaviour patterns and self-perceptions caused by migration. However, most of them are frustrated in the return setting as they cannot find professional or social outlets. They continue to be identified predominantly as housewives within the intra-family division of labour. It is therefore possible to conclude that even though migration had been the cause of many structural and psychological changes regarding gender roles, these changes did not have a long-lasting effect and disappeared upon return home for the migrant women or the return of their husbands for the women who were left behind.

\section{NOTES}

1. This article contains the findings of field research conducted in Turkey between 1990 and 1992. It was made possible by a generous grant offered jointly through the Middle East Awards Programme (MEAwards) and Middle East Research Competition (MERC), sponsored and funded by the Ford Foundation and the Population Council. The author wishes to extend gratitude to Dr. Ali Gitmez of Middle East Technical University, Ankara with whom she worked together in the course of the field surveys.

2. While travelling in this area, a sign indicating the rather ironic name of a village captured the attention of the researchers: Kalankaldi, meaning that "those who stayed have done so for good".

3. The names were then categorized according to addresses to facilitate the frequency of visits per day on the part of the interviewers. Even though some of these addresses were out of date, an adequate number of correct addresses enabled research to proceed. In some cases, neighbours provided researchers with the new addresses of the returnees; in other cases the neighbours were themselves returnees who were then included in the sample.

\section{REFERENCES}

Abadan-Unat, N.

1977 "Implications of migration on emancipation and pseudo-emancipation of Turkish women", International Migration Review, 11(1): 31-57.

1982 "The effect of international labor migration on women's roles: The Turkish case", in Ç. Kagitçibasi (Ed.), Sex Roles, Family and Community in Turkey, Indiana University Turkish Studies 3. 
Abadan-Unat, N., et al. (Eds)

1976 Turkish Workers in Europe, 1960-1975: A Socio-Economic Reappraisal, E. J. Brill, Leiden, Netherlands.

Andezian, $\mathbf{S}$.

1986 "Women's roles in organizing symbolic life: Algerian female immigrants in France", R. J. Simon and C. B. Brettell (Eds), International Migration: The Female Experience, Rowman and Allanheld Publishers.

Brink, J.

1991 "The effect of emigration of husbands on the status of their wives: An Egyptian case", International Journal of Middle East Studies, 23: 201-211.

Brouwer, L., and M. Priester

1983 "Living in between: Turkish women in their homeland and in the Netherlands", in A. Phizacklea (Ed.), One Way Ticket: Migration and Female Labor, Routledge and Kegan Paul.

Davis, F. J., and B. Sherman Heyl

1986 "Turkish women and guestworker migration to West Germany", in R. J. Simon and C. B. Brettell (Eds), International Migration: The Female Experience, Rowman and Allanheld Publishers.

Engelbrektsson, U. B.

1978 The Force of Tradition: Turkish Migrants at Home and Abroad, Gothenburg Studies in Social Anthropology I.

Foner, N.

1979 Jamaica Farewell, Routledge and Kegan Paul, London.

Kosack, G.

1976 "Migrant women: The move to Western Europe - A step towards emancipation?", Race and Class, 17(4): 369-379.

Mehrlander, U.

1979 "Federal Republic of Germany", in D. Kubat et al. (Eds), The Politics of Migration Policies, Center for Migration Studies, New York.

Morokvasic, $\mathbf{M}$.

1983 "Women in migration: Beyond the reductionist outlook", in A. Phizacklea (Ed.), One Way Ticket: Migration and Female Labor, Routledge and Kegan Paul.

Simon, R. J., and C. B. Brettell (Eds)

1986 International Migration: The Female Experience, Rowman and Allanheld Publishers.

SOPEMI-OECD (Organisation for Economic Co-operation and Development) 1988 Continuous Reporting System on Migration, 1987, Paris.

Tienda, M., and K. Booth

1991 "Gender, migration and social change", International Sociology, 6(1): 51-72. 
TABLE 1

MARRIAGE TYPES BY STYLE OF EXPOSURE TO MIGRATION (percentage)

\begin{tabular}{|l|ccc|}
\hline Style & Arranged marriage & Romantic marriage & Other \\
\hline PW & 40 & 61 & - \\
FW & 55 & 40 & 5 \\
FW/out & 84 & 16 & - \\
LB & n/a & $n / a$ & $n / a$ \\
\hline
\end{tabular}

Because percentages in this and the following tables are rounded to the nearest number, totals may not equal 100 .

TABLE 2

FAMILY TYPES BY STYLE OF EXPOSURE TO MIGRATION (percentage)

\begin{tabular}{|l|cc|}
\hline Style & Nuclear family & Extended family \\
\hline PW & 88 & 13 \\
FW & 61 & 39 \\
FW/out & 35 & 65 \\
LB & 39 & 61 \\
\hline
\end{tabular}

TABLE 3

LEVELS OF EDUCATION BY STYLE OF EXPOSURE TO MIGRATION (percentage)

\begin{tabular}{|l|rcccc|}
\hline Style & No school & Primary & Secondary & High (Lycée) & University \\
\hline PW & 6 & 38 & 41 & 9 & 6 \\
FW & 14 & 50 & 21 & 14 & - \\
FW/out & 47 & 50 & 3 & - & - \\
LB & 73 & 25 & 2 & - & - \\
\hline
\end{tabular}


TABLE 4

WAGE WORK EXPERIENCE PRIOR TO EMIGRATION

BY STYLE OF EXPOSURE TO MIGRATION

(percentage)

\begin{tabular}{|l|rcc|}
\hline Style & Wage work & Unemployed & Other \\
\hline & & & \\
PW & 47 & 53 & - \\
FW & 14 & 84 & 2 \\
FW/out & 5 & 95 & - \\
LB & - & 100 & - \\
\hline
\end{tabular}

TABLE 5

COMPARISON OF MIGRANT AND NON-MIGRANT CONTROL GROUPS

IN THE RETURN CONTEXT IN TERMS OF EMPLOYMENT (percentage)

\begin{tabular}{|l|cc|}
\hline Employment & Migrants & Controls \\
\hline Housewife & 88 & 92 \\
Unpaid family work & 8 & 6 \\
Wage work & 3 & 2 \\
\hline
\end{tabular}


TABLE 6

COMPARISONS OF MIGRANTS AND NON-MIGRANTS/CONTROLS

IN THE RETURN CONTEXT IN TERMS OF STRUCTURAL

DETERMINANTS OF GENDER ROLES

(percentage)

\begin{tabular}{|l|cc|}
\hline & Migrants & Non-migrants/Controls \\
\hline Social Security Benefits & & \\
Yes & 32 & 17 \\
No & 63 & 77 \\
Other & 5 & 6 \\
Individual Bank Accounts & 52 & 2 \\
Yes & 27 & 82 \\
No & 21 & 16 \\
Other & & \\
Visiting family/friends & 27 & 44 \\
Chaperoned & 69 & 22 \\
Unchaperoned & 7 & 33 \\
Other & & \\
Voting & 22 & 48 \\
Her husband dictates & 63 & 39 \\
She votes as she wishes & 15 & 13 \\
Other & \\
\hline
\end{tabular}

TABLE 7

COMPARISONS OF MIGRANTS AND NON-MIGRANTS/CONTROLS

IN THE RETURN CONTEXT IN TERMS OF PSYCHOLOGICAL DETERMINANTS OF GENDER ROLES

(percentage)

\begin{tabular}{|l|cc|}
\hline & Migrants & Non-migrants/Controls \\
\hline $\begin{array}{l}\text { Women should give up their work/career } \\
\text { if it conflicts with husbands' and/or } \\
\text { families' well-being }\end{array}$ & & \\
Strongly disagree & & \\
Disagree & 24 & 8 \\
Agree & 26 & 4 \\
Strongly agree & 33 & 23 \\
Don't know & 11 & 62 \\
Stricter discipline should be employed & 5 & 4 \\
in raising girls & & \\
Strongly disagree & & \\
Disagree & 32 & 26 \\
Agree & 32 & 19 \\
Strongly agree & 24 & 19 \\
Don't know & 11 & 36 \\
\hline
\end{tabular}


TABLE 8

IMPACT OF DIFFERENT MIGRATION EXPERIENCES ON GENDER ROLES IN THE RETURN CONTEXT

IN TERMS OF STRUCTURAL DETERMINANTS

(percentage)

\begin{tabular}{|l|rrrrr|}
\hline & PW & FW & FW/out & LB & Control \\
\hline Social Security Benefits & & & & & \\
$\quad$ Yes & 50 & 43 & 5 & 11 & 17 \\
$\quad$ No & 41 & 55 & 92 & 87 & 77 \\
Other & 9 & 2 & 3 & 2 & 6 \\
Individual Bank Accounts & & & & & \\
Yes & 72 & 59 & 23 & 52 & 2 \\
$\quad$ No & 16 & 21 & 46 & 39 & 82 \\
Joint accounts & 12 & 21 & 31 & 10 & 16 \\
Visit family/friends & & & & & \\
$\quad$ Chaperoned & 7 & 19 & 53 & 51 & 44 \\
$\quad$ Unchaperoned & 93 & 74 & 45 & 44 & 22 \\
$\quad$ Other & - & 7 & 3 & 4 & 33 \\
$\quad$ Voting & & & & & \\
$\quad$ Her husband dictates & 4 & 19 & 41 & 54 & 48 \\
$\quad$ She votes as she wishes & 71 & 74 & 43 & 37 & 39 \\
$\quad$ Does not vote & 25 & 7 & 16 & 9 & 13 \\
\hline
\end{tabular}

TABLE 9

IMPACT OF DIFFERENT MIGRATION EXPERIENCES

ON GENDER ROLES IN THE RETURN CONTEXT

IN TERMS OF SOME PSYCHOLOGICAL DETERMINANTS

(percentage)

\begin{tabular}{|c|c|c|c|c|c|}
\hline & PW & FW & FW/out & LB & Control \\
\hline \multicolumn{6}{|l|}{$\begin{array}{l}\text { Women should give up their } \\
\text { work/career if it conflicts with the } \\
\text { husbands' and/or families' well-being }\end{array}$} \\
\hline Strongly disagree & 30 & 26 & 16 & 14 & 8 \\
\hline Disagree & 39 & 23 & 18 & 10 & 4 \\
\hline Agree & 21 & 35 & 42 & 57 & 23 \\
\hline Strongly agree & 9 & 9 & 16 & 17 & 62 \\
\hline Don't know & - & 7 & 8 & 2 & 4 \\
\hline \multicolumn{6}{|l|}{$\begin{array}{l}\text { Stricter discipline should be employed } \\
\text { in raising girls }\end{array}$} \\
\hline Strongly disagree & 42 & 36 & 18 & 9 & 26 \\
\hline Disagree & 36 & 32 & 29 & 27 & 19 \\
\hline Agree & 21 & 23 & 26 & 29 & 19 \\
\hline Strongly agree & - & 7 & 26 & 40 & 36 \\
\hline Don't know & - & 2 & - & - & - \\
\hline
\end{tabular}




\section{L'INFLUENCE DE LA MIGRATION SUR LE ROLE RESPECTIF DES DEUX SEXES : RESULTATS D'UNE ENQUETE SUR LE TERRAIN EN TURQUIE}

Cet article fait état des résultats d'une enquête sur le terrain menée en Turquie auprès de femmes migrantes rentrées au pays et de femmes restées seules en Turquie après le départ de leur mari pour un pays étranger. L'un des objectifs fondamentaux de cette recherche était de dépasser les limites de la problématique existante concernant les femmes et la migration de main-d'oeuvre, qui tend à considérer comme traditionnelle la situation vécue par l'ensemble des femmes migrantes provenant des sociétés peu industrialisées et exportatrices de maind'oeuvre, en dépit des diffërences géographiques, ethniques, éducatives, familiales et autres par lesquelles elles se signalent. Ce travail de recherche s'efforce par conséquent de mettre en lumière l'importance relative des facteurs sous-jacents tels que le mariage et le type de famille, le niveau d'éducation et l'existence ou l'absence d'une expérience de travail rémunéré avant le départ pour l'étranger. La place qu'occupent les femmes dans le processus migratoire, à savoir en tant que pionnières ou "suiveuses", ou en tant que femmes restées seules au foyer, est également très variable. Ces différents statuts, auxquels il faut ajouter l'acquis individuel, permettent d'établir un certain nombre de catégories qui rendent compte des différentes expériences de migration vécues. L'auteur s'efforce en conséquence de faire apparaître l'influence que peuvent avoir différentes expériences migratoires sur le rôle attribué à chacun des deux sexes.

\section{EL IMPACTO DE LA MIGRACION POR SEXOS: CONCLUSIONES DE UNA INVESTIGACION EFECTUADA EN TURQUIA}

Este artículo informa sobre los resultados de una investigación realizada en Turquía entre las migrantes retornantes y aquellas que tuvieron que quedarse en Turquía tras la emigración de sus maridos. Uno de los objetivos fundamentales de esta investigación era sobrepasar los límites de la problemática existente con respecto a las mujeres y a la migración laboral que alude a todas las mujeres migrantes de las sociedades menos desarrolladas y de envío de mano de obra denominándola tradicional a pesar de las diferencias geográficas, étnicas, educativas, familiares y otras. Esa es la razón por la cual se ha intentado llevar a cabo una investigación para poner de relieve la importancia relativa de los antecedentes tales como el matrimonio y los tipos de familia, los niveles de educación y la existencia o carencia de una experiencia laboral 
remunerada antes de la emigración. El tipo de participación de las mujeres en los procesos migratorios, es decir, ya sea como pioneras, seguidoras o personas que permanecen en el país también comprende importantes diferencias. Estos distintos estilos de vida y los antecedentes característicos antes mencionados se combinan a fin de definir la categoría analítica de la experiencia migratoria. Por ello, este estudio constituye un intento de revelar la repercusión que tiene las distintas experiencias migratorias según el sexo de que se trate. 